\title{
Activating Effect of Momordin, Extract of Bitter Melon (Momordica Charantia L.), on the Promoter of Human PPAR $\delta$
}

\author{
Masatoshi Sasa ${ }^{1}$, Ikuo Inoue ${ }^{1}$, Yuichi Shinoda², Seiichiro Takahashi ${ }^{1}$, Makoto Seo $^{2}$, Tsugikazu Komoda², \\ Takuya Awata ${ }^{1}$, and Shigehiro Katayama ${ }^{1}$
}

\author{
${ }^{1}$ Department of Diabetes and Endocrinology, Saitama Medical University, Saitama, Japan \\ ${ }^{2}$ Department of Biochemistry, Saitama Medical University, Saitama, Japan
}

\begin{abstract}
Aim: Bitter melon (Momordica charantia L.) is a common vegetable grown in Okinawa that has also been used recently in medicine for the treatment of diseases such as diabetes, hypertension, and dyslipidemia. Among Bitter melon extracts compounds, we focused on an extract known as momordin in the present study, to examine its effect on peroxisome-proliferator activated-receptor (PPAR) $\delta$ (also called PPAR $\delta$ in rodents) expression and promoter activity of the human PPAR $\delta$ gene.

Methods: A human PPAR $\delta$ promoter-reporter plasmid was made as a template from a BAC CLONE (RPCI-11C) containing a -3076 bp (BgII site) +74 bp (EcoRI site) sequence. Luciferase assay of PPAR $\delta$ promoter activity was performed using HepG2 cells.

Results: 10 and $25 \mathrm{nM}$ Momordin significantly increased the expression of PPAR $\delta$ mRNA 1.5-fold (relative to the control). Moreover, 10 and $25 \mathrm{nM}$ Momordin significantly increased PPAR $\delta$ promoter activity in a dose-dependent manner, reaching more than 1.5-fold relative to the control.

Conclusion: Our present data obtained through successful cloning of the PPAR $\delta$ promoter demonstrate that $\operatorname{PPAR} \delta$ production and activation are upregulated through $\operatorname{PPAR} \delta$ promoter activity following momordin treatment.
\end{abstract}

J Atheroscler Thromb, 2009; 16:888-892.

Key words; Bitter melon, PPAR $\beta / \delta$, Momordin, PPAR $\beta / \delta$ promoter

\section{Introduction}

Peroxisome proliferator-activated receptor (PPAR) $\beta / \delta$ is the least well-defined subtype among the PPARs. Recent biological studies have disclosed that its activation significantly increases high-density lipoprotein (HDL)-cholesterol levels, and it influenced glycemic control in a primate model of metabolic syndrome ${ }^{1-3)}$. Recent studies also suggest that the overexpression of $\operatorname{PPAR} \beta / \delta$ in adipose tissue protects against diet-induced obesity in mice, and treatment with a PPAR $\beta / \delta$-selective agonist reduces weight gain without affecting food intake in fat-fed mice ${ }^{4)}$. During some synthetic ligands of PPAR, have been reported little is known about the

Address for correspondence: Ikuo Inoue, Department of Diabetes and Endocrinology, Saitama Medical University, 38 Morohongo, Moroyama, Iruma-gun, Saitama 350-0495, Japan E-mail: i1901018@saitama-med.ac.jp

Received: February 24, 2009

Accepted for publication: June 25, 2009
$\operatorname{PPAR} \beta / \delta$ agonist in extracts of natural foods.

Bitter melon, recognized as having medicinal value in India and traditional Chinese medicine, is a common vegetable in tropical areas. This vegetable showed a hypoglycemic effect in diabetic rats as well as in human subjects with type 2 diabetes mellitus but the mechanism for the hypoglycemic and hypolipidemic effects of bitter mellon is still unclear. It has numerous other constituents, including proteins momordin, glycosides, saponins, vitamin $\mathrm{A}$, vitamin $\mathrm{C}$, $\beta$-carotene and minerals ${ }^{5)}$.

Momordin might preventing diabetes, hypertension and dyslipidemia, which involves activated c-Jun $\mathrm{NH}_{2}$-terminal kinase (JNK). Momordin inhibits activator protein-1 (AP-1) activation induced by phorbol ester $^{6}$. JNK signaling pathways are stimulated through AP-1 activation ${ }^{7)}$. Activated JNK could be critical in causing diabetes, insulin resistance and obesity ${ }^{8)}$. Moreover, momordin also showed inhibitory action against both jun/jun homodimer and jun/fos het- 
erodimer. Thus, we selected momordin as a nuclear factor modulator among many kinds of compounds in bitter melon.

In the present study, we investigated the effect of momordin on the regulation of $\mathrm{PPAR} \beta / \delta$ expression in promoter activity of the human PPAR $\beta / \delta$ gene.

\section{Materials and Methods}

\section{Reagents and Cell Culture}

Momordin (Code number: 10-118) was purchased from Inland Laboratories (Import agent: Wako Pure Chemical Industries, Ltd., Tokyo, Japan). Momordin was dissolved in dimethyl sulfoxide (DMSO). In all assays, the final concentrations of DMSO were less than $0.5 \%$. The human hepatoblastoma cell line (HepG2 cells) was purchased from JCRB (cell number; JCRB1054) cultured in Dulbecco's modified Eagle's medium (DMEM) (Invitrogen) containing 10\% heat-inactivated fetal bovine serum (FBS) (JRH Biosciences) and PNS Antibiotic Mixture (Invitrogen) at $37^{\circ} \mathrm{C}$ in $5 \% \mathrm{CO}_{2}$.

\section{Cloning of the PPAR $\beta / \delta$ Promoter and Plasmid Constructions}

To generate human $\mathrm{PPAR} \beta / \delta$ promoter-reporter plasmid, we referred to the genomic sequence that has been reported previously ${ }^{9)}$. Human PPAR promoterreporter plasmid was made as template form $\mathrm{BAC}$ CLONE (RPCI-11C), containing -3076 bp (BgII site) +74 bp (EcoRI site). The transcriptional initiation site of PPAR was selected (Gene Bank accession NM_006238, NM_001039694). Moreover, a series of deletion constructs was produced using PCR or restriction sites in all promoters.

\section{Luciferase Assay of PPAR $\beta / \delta$ Promoter Activity}

HepG2 cells were transfected using Lipofectami$\mathrm{ne}^{\mathrm{TM}} 2000$ (Invitrogen) according to the manufacturer's protocols. The cells $\left(1 \times 10^{5}\right.$ cells/well $)$ were seeded in 24-well plates (Falcon) and incubated for 18 hours before transfection, using Lipofectamine ${ }^{\mathrm{TM}}$ 2000 with $1 \mu \mathrm{g}$ human PPAR $\beta / \delta$ promoter-reporter plasmid and $0.1 \mu \mathrm{g}$ pRL-TK (Promega), a renilla luciferase reporter vector as an internal control for transfection efficiency. After 3 hours, the transfection medium was replaced by $10 \%$ FBS-DMEM plus various amounts of momordin $(0,0.1,0.2,0.5,1,2,5$, $10,25 \mathrm{nM}$ ) or vehicle (DMSO or distilled water) and the cells were incubated for 24 hours. Luciferase activities were quantified using a Dual-Luciferase ${ }^{\circledR}$ Reporter Assay System (Promega) according to the manufacturer's protocols.
Real-Time Reverse Transcription (RT)-PCR Analysis

For PPAR $\beta / \delta$, HepG2 cells $\left(2 \times 10^{5}\right.$ cells/dish $)$ were incubated with various amounts of momordin $(0,0.1,0.2,0.5,1,2,5,10,25 \mu \mathrm{M})$ at $37^{\circ} \mathrm{C}$ for 24 hours. After treatment with momordin, cells were homogenized in $1 \mathrm{~mL}$ ISOGEN (Nippongene), and then total RNA was extracted with chloroform and precipitated with ethanol. First-strand cDNA was generated from total RNA with random hexamers and $\mathrm{MuLV}$ transcriptase (Applied Biosystems) according to the manufacturer's protocols. PCR reactions were performed with TaqMan ${ }^{\circledR}$ Universal PCR Master Mix and TaqMan ${ }^{\circledR}$ Gene Expression Assays (Applied Biosystems). Identification numbers of the assay mixture of target gene-specific primers and probes were as follows: PPAR, Hs00606407_m1; 18S ribosomal RNA (house-keeping gene), Hs99999901_s1. Real-time PCR reactions were performed with thermal cycling conditions of 2 minutes at $50^{\circ} \mathrm{C}, 10$ minutes at $95^{\circ} \mathrm{C}$, and 40 cycles of 15 seconds at $95^{\circ} \mathrm{C}$ and 1 minute at $60^{\circ} \mathrm{C}$ using the ABI PRISM ${ }^{\mathrm{TM}} 7900 \mathrm{HT}$ Sequence Detection System (Applied Biosystems). PPAR levels were normalized to $18 \mathrm{~S}$ ribosomal RNA levels, and are presented as fold differences of momordin treated cells compared with untreated cells.

\section{Statistical Analysis}

All data are presented as the means \pm SEM. Statistical analysis was performed using ANOVA followed by the Dunnett test or Scheffe test (StatView software). Statistical significance was considered as $p$ value $<0.05$.

\section{Results}

\section{Momordin Increased PPAR mRNA Expression}

Firstly, we examined the effect of momordin on PPAR $\beta / \delta$ mRNA expression in HepG2 cells. We decided the appropriate incubation time and dose, as shown in Fig. 1, 2. The time-course study for PPAR $\beta / \delta$ mRNA expression in HepG2 cells treated with $10 \mathrm{nM}$ momordin is shown in Fig. 1. Momordin significantly increased PPAR $\beta / \delta$ mRNA expression by 1.5 -fold, 1.3 fold (versus the control) at 12 and 24 hours, respetively. We next examined the effect of various amounts of momordin for 24 hours on PPAR $\delta$ mRNA expression in HepG2. In Fig. 2, momordin (10 and $25 \mathrm{nM})$ significantly increased PPAR $\delta$ mRNA expression by 1.5 -fold (versus the control).

On the other hand, higher concentrations of momordin treatment $(50,100$ and $250 \mathrm{nM})$ did not increase $\operatorname{PPAR} \beta / \delta$ mRNA expression significantly (data not shown). 


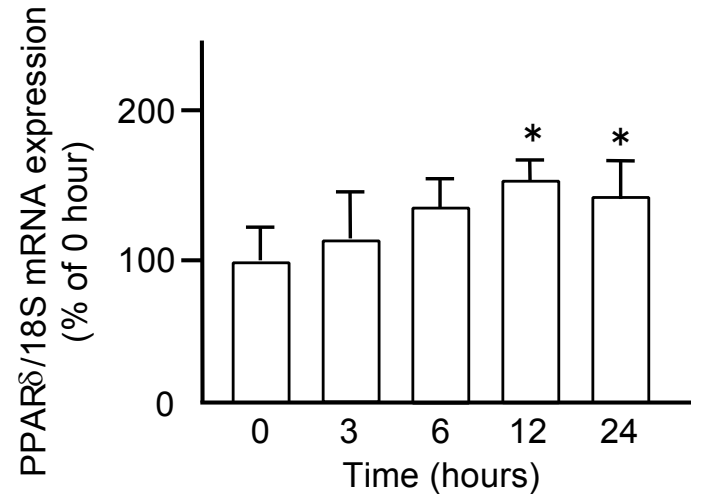

Fig. 1. Effects of momordin incubation time on PPAR mRNA expression by RT-PCR analysis.

$10 \mathrm{nM}$ momordin significantly increased $\operatorname{PPAR} \beta / \delta$ mRNA expression at 12 and 24 hours. All data are presented as the means \pm SEM. ${ }^{*} p<0.05$ vs 0 hour

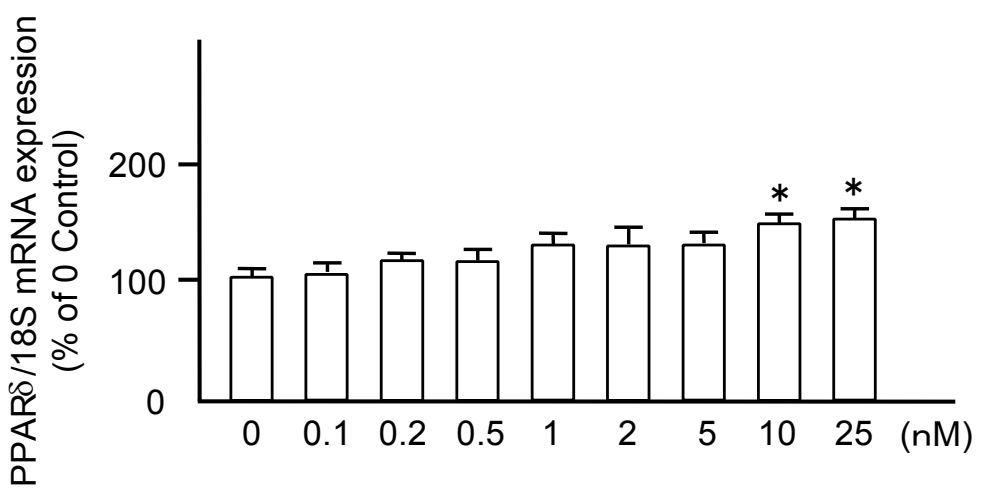

Fig. 2. Effects of momordin on PPAR mRNA expression by RT-PCR analysis.

Momordin significantly increased PPAR $\beta / \delta$ mRNA expression dose-dependently at 24 hours. All data are presented as the means \pm SEM. ${ }^{*} p<0.05$ vs $0 \mathrm{nM}$

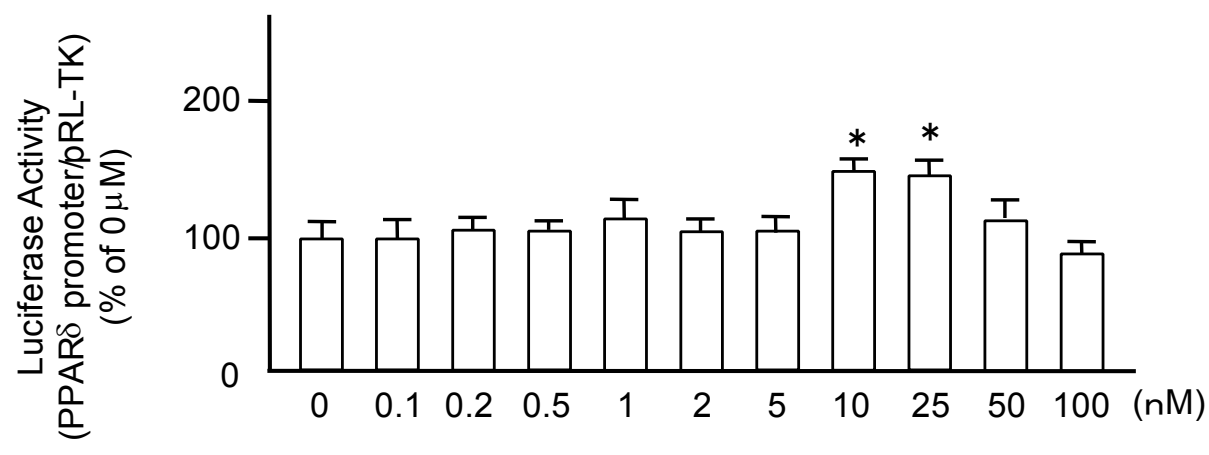

Fig. 3. Effects of momordin on human $\operatorname{PPAR} \delta$ promoter activity.

Momordin significantly increased PPAR $\delta$ promoter activity in a dose-dependent manner. All data are presented as the means \pm SEM. ${ }^{*} p<0.05$ vs $0 \mathrm{nM}$

\section{Momordin Increased Human PPAR $\delta$ Promoter Activity}

To investigate the mechanism by which momordin increases PPAR $\delta$ mRNA expression, we cloned the human PPAR $\delta$ promoter region $(-3076$ to +74 bp) and examined promoter activity in HepG2 cells transfected with the human PPAR $\delta$ promoter-reporter plasmid. Fig. 3 shows PPAR $\delta$ promoter activity following treatment of HepG2 cells with various amounts of momordin for 24 hours. Momordin significantly increased PPAR $\delta$ promoter activity in a dose-dependent manner by more than 1.5 -fold (versus the control).

\section{Discussion}

The present study was undertaken to evaluate the effect of momordin (extract of Momordica charan- tia) by our successful cloning of the $\operatorname{PPAR} \beta / \delta$ promoter. In our results, momordin regulated PPAR $\delta$ production through PPAR $\delta$ promoter activity. Bitter melon (Momordica charantia L.), which has hypoglycemic and hypotriglyceridemic effects ${ }^{10)}$, is a common vegetable in Okinawa that has also been used recently in medicine for the treatment of diabetes, hypertension and dyslipidemia ${ }^{11,12)}$; however, the mechanism and active compounds responsible for these biological effects of bitter mellon have not been fully elucidated. Bitter mellon also has numerous other constituents, including proteins, momordin, glycosides, saponins, and minerals. It is also rich in vitamins $\mathrm{A}$ and $\mathrm{C}$ and $\beta$-carotene, as well as iron, phosphorus, and potas$\operatorname{sium}^{5)}$.

In this study, we revealed that momordin has anti-glycemia and anti-lipidemia effects on target genes of PPAR $\beta / \delta$-regulated $\operatorname{PPAR} \beta / \delta$ promoter activity. 
The effect of momordin on nuclear factors is interesting. It has also been reported that momordin suppressed osteoclastogenesis through the inhibition of $\mathrm{NF}-\kappa \mathrm{B}$ and $\mathrm{AP}-1^{13)}$. In animal experiments, mormordin showed both the inhibition of AP-1 transcriptional activity and cellular cytotoxicity. By accumulating data for nuclear factor regulation by momordin, further study may reveal the unknown mechanisms of momordin ${ }^{14)}$.

Telmisartan, an angiotensin II receptor antagonist with partial PPAR $y$ agonist activity, modulates the metabolism involving atherogenecity ${ }^{15,16)}$. Other drugs also have a mechanism involving the PPARs system $^{17-20)}$. The generation of monoclonal antibodies against human peroxisome proliferator-activated receptors ${ }^{21)}$ has developed new treatment by clarifying atherogenesis $^{22)}$. Although the action of each PPARs is interesting, PPAR $\delta$ modulator is not currently available as a drug. Many studies have revealed that PPAR $\delta$ controls the metabolic genes involved in glucose and lipid homeostasis. (i.e., mitochondrial $\beta$-oxidation/ peroxisomal $\beta$-oxidation-related genes, UCP (uncoupling protein) 2, glucose oxidation, PDK (pyruvate dehydrogenase kinase) 4, mitochondrial HMG-CoA synthase etc.) ${ }^{23-26)}$; therefore, momordin may be used as a natural PPAR $\delta$ modulator.

Care should be taken regarding the concentration of this agent. A higher concentration (100 nM) of momordin, which act as a ribosome-inactivating protein (RIP $)^{27)}$, induced apoptosis in a bioassay ${ }^{28)}$. In our results, a higher concentration of momordin did not increase PPAR $\delta$ expression and promoter activity, but it is uncertain whether the concentration of momordin used in our experiment is physiological.

More investigation may reveal the effect of PPARs on not only atherogenesis but also other diseases ${ }^{29)}$.

\section{Reference}

1) Lee $\mathrm{CH}$, Olson P, Evans RM: Minireview: lipid metabolism, metabolic diseases, and peroxisome proliferator-activated receptors. Endocrinology, 2003; 144: 2201-2207

2) Kunishima C, Inoue I, Oikawa T, Nakajima H, Komoda T, Katayama S: Activating effect of benzbromarone, a uricosuric drug, on peroxisome proliferator-activated receptors. PPAR Res, 2007; Article ID 36092, PMID 18274627

3) Shimazu T, Inoue I, Araki N, Asano Y, Sawada M, Furuya D, Nagoya H, Greenberg JH: A peroxisome proliferatoractivated receptor-gamma agonist reduces infarct size in transient but not in permanent ischemia. Stroke, 2005; 36: 353-359

4) Evans RM, Barish GD, Wang YX: PPARs and the complex journey to obesity. Nat Med, 2004; 10: 355-361

5) Momordica charantia (bitter melon). Monograph, Altern Med Rev, 2007; 12: 360-363
6) Park S, Lee DK, Whang YH, Yang CH: Momordin I, a compound of ampelopsis radix, inhibits AP-1 activation induced by phorbol ester. Cancer Lett, 2000; 152: 1-8

7) Zagariya A, Mungre S, Lovis R, Birrer M, Ness S, Thimmapaya B, Pope R: Tumor necrosis factor alpha gene regulation: enhancement of $\mathrm{C} / \mathrm{EBP}$ beta-induced activation by c-Jun. Mol Cell Biol, 1998; 18: 2815-2824

8) Bennett BL, Satoh Y, Lewis AJ: JNK: a new therapeutic target for diabetes. Curr Opin Pharmacol, 2003; 3: 420425

9) Pineda Torra I, Jamshidi Y, Flavell DM, Fruchart JC, Staels B: Characterization of the human PPAR $\alpha$ promoter: identification of a functional nuclear receptor response element. Mol Endocrinol, 2002; 16: 1013-1028

10) Chuang CY, Hsu C, Chao CY, Wein YS, Kuo YH, Huang CJ: Fractionation and identification of 9c, 11t, 13t-conjugated linolenic acid as an activator of PPAR $\alpha$ in bitter gourd (Momordica charantia L.). J Biomed Sci, 2006; 13: 763-772

11) Ojewole JA, Adewole SO, Olayiwola G: Hypoglycaemic and hypotensive effects of Momordica charantia Linn (Cucurbitaceae) whole-plant aqueous extract in rats. Cardiovasc J S Afr, 2006; 17: 227-232

12) Tuekpe MK, Todoriki H, Sasaki S, Zheng KC, Ariizumi M: Potassium excretion in healthy Japanese women was increased by a dietary intervention utilizing home-parcel delivery of Okinawan vegetables. Hypertens Res, 2006; 29: 389-396

13) Hwang YH, Lee JW, Hahm ER, Jung KC, Lee JH, Park $\mathrm{CH}$, Rhee HS, Ryu JM, Kim HK, Yang CH: Momordin $\mathrm{I}$, an inhibitor of AP-1, suppressed osteoclastogenesis through inhibition of NF-kappaB and AP-1 and also reduced osteoclast activity and survival. Biochem Biophys Res Commun, 2005; 337: 815-823

14) Inoue I, Itoh F, Aoyagi S, Tazawa $S$, Kusama H, Akahane M, Mastunaga T, Hayashi K, Awata T, Komoda T, Katayama $S$ : Fibrate and statin synergistically increase the transcriptional activities of $\operatorname{PPAR} \alpha / \operatorname{RXR} \alpha$ and decrease the transactivation of NFkappaB. Biochem Biophys Res Commun, 2002; 290: 131-139

15) Hitsumoto T, Takahashi M, lizuka T, Shirai K: Effect of the angiotensin II receptor antagonist telmisartan on lipoprotein lipase mass in preheparin serum. J Atheroscler Thromb, 2008; 15: 138-145

16) Nakaya K, Ayaori M, Hisada T, Sawada S, Tanaka N, Iwamoto N, Ogura M, Yakushiji E, Kusuhara M, Nakamura H, Ohsuzu F: Telmisartan enhances cholesterol efflux from THP-1 macrophages by activating PPAR $\gamma$. J Atheroscler Thromb, 2007; 14: 133-141

17) Inoue I, Shinoda Y, Ikeda M, Hayashi K, Kanazawa K, Nomura M, Matsunaga T, Xu H, Kawai S, Awata T, Komoda T, Katayama S: CLOCK/BMAL1 is involved in lipid metabolism via transactivation of the peroxisome proliferator-activated receptor (PPAR) response element. J Atheroscler Thromb, 2005; 12: 169-174

18) Saiki A, Murano T, Watanabe F, Oyama T, Miyashita Y, Shirai K: Pitavastatin enhanced lipoprotein lipase expression in 3T3-L1 preadipocytes. J Atheroscler Thromb, 2005; 12: 163-168

19) Mori Y, Tokutate Y, Oana F, Matsuzawa A, Akahane S, 
Tajima N: Bezafibrate-induced changes over time in the expression of uncoupling protein (UCP) mRNA in the tissues: a study in spontaneously type 2 diabetic rats with visceral obesity. J Atheroscler Thromb, 2004; 11: 224-231

20) Inoue I, Hayashi K, Yagasaki F, Nakamura K, Matsunaga $\mathrm{T}$, Xu H, Inukai K, Awata T, Komoda T, Katayama S: Apoptosis of endothelial cells may be mediated by genes of peroxisome proliferator-activated receptor gamma 1 $(\operatorname{PPAR} \gamma 1)$ and PPAR $\alpha$ genes. J Atheroscler Thromb, 2003; 10: 99-108

21) Tanaka T, Takeno T, Watanabe $Y$, Uchiyama $Y$, Murakami T, Yamashita H, Suzuki A, Aoi R, Iwanari H, Jiang SY, Naito M, Tachibana K, Doi T, Shulman AI, Mangelsdorf DJ, Reiter R, Auwerx J, Hamakubo T, Kodama T: The generation of monoclonal antibodies against human peroxisome proliferator-activated receptors (PPARs). J Atheroscler Thromb, 2002; 9: 233-242

22) Auwerx J, Schoonjans K, Fruchart JC, Staels B: Regulation of triglyceride metabolism by PPARs: fibrates and thiazolidinediones have distinct effects. J Atheroscler Thromb, 1996; 3: 81-89

23) Reilly SM, Lee CH: PPAR delta as a therapeutic target in metabolic disease. FEBS Lett, 2008; 582: 26-31

24) Tanaka $T$, Yamamoto J, Iwasaki $S$, Asaba $H$, Hamura $H$, Ikeda Y, Watanabe M, Magoori K, Ioka RX, Tachibana K, Watanabe Y, Uchiyama Y, Sumi K, Iguchi H, Ito S, Doi T, Hamakubo T, Naito M, Auwerx J, Yanagisawa M, Kodama T, Sakai J: Activation of PPAR $\delta$ induces fatty acid beta-oxidation in skeletal muscle and attenuates metabolic syndrome. Proc Natl Acad Sci U S A, 2003; 100:
15924-15929

25) Lee CH, Olson P, Hevener A, Mehl I, Chong LW, Olefsky JM, Gonzalez FJ, Ham J, Kang H, Peters JM, Evans RM: PPAR $\delta$ regulates glucose metabolism and insulin sensitivity. Proc Natl Acad Sci U S A, 2006; 103: $3444-$ 3449

26) Oliver WR Jr, Shenk JL, Snaith MR, Russell CS, Plunket $\mathrm{KD}$, Bodkin NL, Lewis MC, Winegar DA, Sznaidman ML, Lambert MH, Xu HE, Sternbach DD, Kliewer SA, Hansen BC, Willson TM: A selective peroxisome proliferator-activated receptor $\delta$ agonist promotes reverse cholesterol transport. Proc Natl Acad Sci U S A, 2001; 98: 53065311

27) Barbieri L, Brigotti M, Perocco P, Carnicelli D, Ciani M, Mercatali L, Stirpe F: Ribosome-inactivating proteins depurinate poly (ADP-ribosyl)ated poly (ADP-ribose) polymerase and have transforming activity for $3 \mathrm{~T} 3$ fibroblasts. FEBS Lett, 2003; 538: 178-182

28) Bolognesi A, Tazzari PL, Olivieri F, Polito L, Falini B, Stirpe F: Induction of apoptosis by ribosome-inactivating proteins and related immunotoxins. Int J Cancer, 1996; 68: 349-355

29) Maruyama S, Kato K, Kodama M, Hirono S, Fuse K, Nakagawa O, Nakazawa M, Milda T, Yamamoto T, Watanabe K, Aizawa Y: Fenofibrate, a peroxisome proliferatoractivated receptor alpha activator, suppresses experimental autoimmune myocarditis by stimulating the interleukin-10 pathway in rats. J Atheroscler Thromb, 2002; 9: $87-92$ 